Article

\title{
Early Effects of Afforestation with Willow (Salix purpurea, "Hotel") on Soil Carbon and Nutrient Availability
}

\author{
Joels Ens ${ }^{1}$, Richard E. Farrell ${ }^{1}$ and Nicolas Bélanger ${ }^{2, *}$
}

1 Department of Soil Science, University of Saskatchewan, 51 Campus drive, Saskatoon, SK, S7N 5A8, Canada; E-Mails: j.ens@usask.ca (J.E.); r.farrell@usask.ca (R.E.F.)

2 Department of Science and Technology, University of Quebec, 5800 Saint-Denis Street, Office 1105, Montreal, QC, H2S 3L5, Canada

* Author to whom correspondence should be addressed; E-Mail: belanger.nicolas@teluq.ca; Tel.: +1-514-843-2015; Fax: +1-514-843-2160.

Received: 25 December 2012; in revised form: 8 February 2013 / Accepted: 25 February 2013 / Published: 12 March 2013

\begin{abstract}
Willow (Salix spp.) is currently being researched as a source of biomass energy in Canada. However, it is not certain whether afforestation with willow plantations will enhance or diminish soil $\mathrm{C}$ storage and nutrient availability. Trees are known to have pronounced effects on biologically mediated nutrient cycling processes which can increase nutrient availability, but willows are known to be nutrient demanding. In this paper, the net effect of plantation establishment is examined at nine sites across the prairie and southern Ontario regions of Canada. Carbon, N, P, K, Ca and Mg levels in soils and harvestable biomass were compared between willow plantations and paired reference sites at the end of the first three-year rotation. Soils were depleted in total $\mathrm{C}\left(-2.22 \mathrm{mg} \cdot \mathrm{g}^{-1}, p<0.05\right)$, inorganic $\mathrm{N}\left(-3.12 \mu \mathrm{g} \cdot \mathrm{N} \cdot \mathrm{g}^{-1}, p<0.10\right)$, exchangeable $\mathrm{K}\left(-0.11 \mathrm{cmol}_{\mathrm{c}} \cdot \mathrm{kg}^{-1}, p<0.10\right)$ and leachable $\mathrm{P}\left(-0.03 \mathrm{mg} \cdot \mathrm{g}^{-1}, p<0.10\right)$. Exchangeable $\mathrm{Ca}$ was found to be consistently depleted only at the 20-40 depth. Depletion of soil $\mathrm{K}$ was more heavily influenced by disturbance, whereas soil $\mathrm{N}$ was directly affected by willow $\mathrm{N}$ uptake. Sites with greater growth and biocycling stabilized soil $\mathrm{P}$ concentrations.
\end{abstract}

Keywords: biomass energy; short rotation intensive culture; Salix; fast growth; carbon sequestration; soil nutrient depletion; base cations; nitrogen; phosphorus 


\section{Introduction}

Intensive (agro)forestry for biomass energy is growing in Canada. Willow (Salix spp.) is one genus with potential to maintain high rates of productivity despite climatic limitations [1]. Several willow species can be found growing across Canada, typically associated with low lying areas [2]. Because of its hardiness, fast growth rate, and ability to regrow vegetatively, willow is ideally suited to short rotation intensive culture (SRIC), often in the context of energy production [3].

Although tree growth has been shown to respond favorably to fertilization [4,5], trees are most frequently forced to be resourceful in nutrient acquisition [6,7]. This is made possible by the trees' ability to exploit nutrient pools through an extensive root system and to recycle nutrients efficiently. The introduction of trees in agricultural landscapes frequently has dramatic effects on soil nutrient availability by: (1) accessing resources from deeper within the soil profile; (2) augmenting soil mineral weathering by producing acidic exudates (roots) that act as chelators; (3) changing hydrologic conditions and increasing evapotranspiration to decrease leaching; (4) storing nutrients within their biomass and their leaves which are then returned to the soil via litterfall or other pathways; (5) filtering of dry particulates by the forest canopy; and (6) altering $\mathrm{pH}$ and suppressing competition [8-10]. Afforestation has also been reported to decrease soil bulk density in some but not all cases [11].

Nutrient cycling in SRIC, however, is not as efficient as in a natural forest [10]. This is because fast growing tree species such as Salix spp. use high levels of nutrients [12-15] and some of the nutrients the trees take up will be lost from the soils for future use when the biomass is extracted $[5,10]$. However, some of the biologically mediated processes identified above may increase nutrient sequestration and availability and therefore, rapid tree growth does not always result in a reduction of soil nutrients. In fact, some of these processes may add nutrients to the soil system and may even be enhanced via increased growth [16]. For example, the larger amount of leaf surface area of a faster growing tree will filter out more particulates that are added to the soil as they are washed off by rain [10]. Increased root growth and acidic exudate production can augment the release of nutrients from parent material mineral weathering [10]. Additionally, when a site is nutrient poor, trees increase their root to shoot ratio [17] which may result in enhanced weathering of parent materials due to increased organic acid production [18,19]. As well as these additions, it may be that while larger trees are taking up more nutrients, they are also increasing the recycling of these nutrients through decreased leaching. Greater evapotranspiration and a more complex/developed root system reduces the amount of nutrient-rich waters percolating and leaving the soil system $[10,16]$.

To further complicate the issue, changes to soil nutrient pools, soil $\mathrm{C}$ and soil $\mathrm{pH}$ all depend on the previous land use [20]. For each soil property, there are a number of ways that plantation establishment can have an effect. Firstly, plantation establishment can have a unidirectional effect. This would be the case if willow always caused a decrease in available $\mathrm{N}$ as it is exported with biomass until it is no longer economically viable to produce willow on that site. The rate of depletion will depend on the initial concentration in the soil and the affinity of willow for that nutrient. In the case of $\mathrm{C}$, in other agroforestry systems, the literature describes a different way for change to occur. For each soil and climate, there is roughly a steady state equilibrium of soil $\mathrm{C}$ depending on land use [21-23]. Agroforestry systems tend to have higher soil $\mathrm{C}$ than annual crops but lower than pastures [21]. Land use change initiates a gradual change in soil $\mathrm{C}$ to the steady state associated with the particular land 
use [21]. Therefore, willow plantation establishment on pasture may lead to a decrease in soil $\mathrm{C}$ but establishment on annual cropland may increase soil C.

Thus, questions arise as to the impact of willow plantations on soils. Do willow plantations provide the right conditions for enhanced nutrient and $\mathrm{C}$ sequestration? Are the nutrients removed with biomass irreplaceable without human intervention? Investigations of the nutritional status of willow plantations needs to be extended from measurement of nutrient export rates to include the effect of land use change on soil nutrient pools. We also need to know the nature of these changes. This information is crucial for determining the total effect of cultivating willow and the requirements of the system for any inputs and supplements both during and after production. Therefore, the objectives of this study are to measure nutrient export and quantify differences in soil nutrient and $\mathrm{C}$ stocks between plantation and reference soils as a result of willow plantation establishment and first rotation harvest across a wide range of soils and land-use in Canada. The hypothesis that willow plantation establishment maintains soil nutrients, is tested. The nature and direction of the changes are also examined in order to understand those pools that may be of concern for maintaining productivity in the long term.

\section{Experimental Section}

\subsection{Experimental Design}

Nine sites across the Canadian prairies and extending into eastern Canada were included in this study, representing a wide variety of soil types and previous land uses (Table 1). Aboveground vegetation was removed and soils were tilled in preparation for unrooted cuttings of the "Hotel" clone of $S$. purpurea. Due to the large geographic scale and variability in soils, climate and previous land uses, it was essential for plantation success that site preparation and management be adaptive to specific site characteristics. Variability associated with differences in management was deemed to be minimal and is addressed in the text where possible impacts may have occurred. It is also important to recognize that plantation establishment is a significant source of disturbance. Cuttings were planted in triple rows at a spacing of $60 \mathrm{~cm}$ within rows and $200 \mathrm{~cm}$ between rows. A mix of manual, mechanical and chemical weed treatments was used on a site by site basis to control competition by weeds. Plantations were established in 2005 and 2006 and sampled in the third (i.e., final) year of the first rotation (i.e., 2007 and 2008) with soil samples being collected in August (during peak activity) and stems in October/November (end of growing season). Whereas willow bioenergy plantations are typically coppiced at the end of the first year to promote branching, the sites included in this study — with the exception of the site at Guelph, ON (GUE) — were not coppiced at the end of the first year. GUE was coppiced after the first year and then allowed to complete a three year rotation such that, at this site, the land use change had occurred four years previous (as opposed to three years for the other sites). At each site, five $3.2 \mathrm{~m} \times 1.8 \mathrm{~m}$ plots from within the plantation were selected randomly, exclusive of areas with very poor survival, together with five reference plots from the immediately adjoining area. The reference sites were chosen at the time of sampling to be characteristic of the land-use at the time the plantations were established based on site specific histories and soil texture analyses. Likewise, the reference sites were selected on soils comparable to 
those in the plantations. Unfortunately, no perfect match was found for the site at Smoky Lake, AB (SMO), where the plantation received $\mathrm{N}$ and $\mathrm{P}$ fertilizers but the reference had not. Within each $3.2 \mathrm{~m} \times 1.8 \mathrm{~m}$ plot, mineral soil cores $(n=3)$ were collected at $0-20$ and 20-40 cm increments; one core was taken from the centre of the triple row, one from the edge of the triple row and one from halfway between triple rows and analyzed separately. Depths of 0-20 and 20-40 cm were chosen to allow soil samples to be consistent across a wide variety of soils and plough depths and still provide data from near surface and subsurface soils. Stems from the trees originating within each plot were harvested and weighed in the field. A 1-2 kg random subsample, incorporating whole stems, was dried and reweighed to convert fresh weight to dry weight for each plot [24,25]. Stems were weighed and collected at only seven of the nine sites as two sites had previously been coppiced in the spring.

Table 1. Site names, locations, history, soil texture, soil $\mathrm{pH}$, precipitation and harvested biomass summary data for nine S. purpurea "Hotel" plantations included in this study.

\begin{tabular}{|c|c|c|c|c|c|c|c|c|}
\hline Site (ID) & $\begin{array}{l}\text { Geographic } \\
\text { Coordinates }\end{array}$ & $\begin{array}{c}\text { Site } \\
\text { History }\end{array}$ & $\begin{array}{c}\text { Soil } \\
\text { Texture }^{\dagger}\end{array}$ & $\begin{array}{c}\text { Soil pH } \\
\text { (SE) }\end{array}$ & $\begin{array}{c}\text { Mean Annual } \\
\text { Precipitation } \\
\text { for } \\
\text { Production } \\
\text { Years (SE) }\end{array}$ & $\begin{array}{c}\text { Year } \\
\text { Planted }\end{array}$ & $\begin{array}{c}\text { Year } \\
\text { Sampled }\end{array}$ & $\begin{array}{c}\text { Harvested } \\
\text { Biomass } \\
\text { (SE) }\end{array}$ \\
\hline & & & & & $\mathbf{m m}$ & & & $\mathrm{Mg} \cdot \mathrm{ha}^{-1}$ \\
\hline $\begin{array}{l}\text { Ellerslie Research } \\
\text { Station, AB (ELL) }\end{array}$ & $\begin{array}{c}53^{\circ} 25^{\prime} \mathrm{N} \\
113^{\circ} 31^{\prime} \mathrm{W}\end{array}$ & $\begin{array}{l}\text { Cereal } \\
\text { crops }\end{array}$ & $\begin{array}{l}\text { Silty Clay } \\
\text { Loam }\end{array}$ & $6.0(0.1)$ & 404 (43) & 2005 & 2007 & $\mathrm{~N} / \mathrm{A}^{\dagger \dagger}$ \\
\hline $\begin{array}{c}\text { Smoky Lake, AB } \\
\text { (SMO) }\end{array}$ & $\begin{array}{c}54^{\circ} 07^{\prime} \mathrm{N} \\
112^{\circ} 24^{\prime} \mathrm{W}\end{array}$ & $\begin{array}{c}\text { Tree } \\
\text { nursery }\end{array}$ & $\begin{array}{l}\text { Sandy } \\
\text { Loam }\end{array}$ & $5.1(0.1)$ & $412(27)$ & 2005 & 2007 & $5.4(0.1)$ \\
\hline $\begin{array}{c}\text { Lakeshore Tree } \\
\text { Nursery, SK } \\
\text { (LAK) }\end{array}$ & $\begin{array}{c}52^{\circ} 00^{\prime} \mathrm{N} \\
106^{\circ} 45^{\prime} \mathrm{W}\end{array}$ & Pasture & $\begin{array}{l}\text { Silty Clay } \\
\text { Loam }\end{array}$ & $8.3(0.0)$ & 454 (53) & 2005 & 2007 & $18.4(1.2)$ \\
\hline $\begin{array}{c}\text { University of } \\
\text { Saskatchewan, SK } \\
\text { (UOS) }\end{array}$ & $\begin{array}{c}52^{\circ} 07^{\prime} \mathrm{N} \\
106^{\circ} 36^{\prime} \mathrm{W}\end{array}$ & $\begin{array}{l}\text { Cereal } \\
\text { crops }\end{array}$ & Clay & $6.6(0.1)$ & $382(74)$ & 2006 & 2008 & $5.3(0.8)$ \\
\hline $\begin{array}{c}\text { Portage la Prairie, } \\
\text { MB (POR) }\end{array}$ & $\begin{array}{l}49^{\circ} 57^{\prime} \mathrm{N} \\
98^{\circ} 10^{\prime} \mathrm{W}\end{array}$ & Vegetables & Silt Loam & $8.3(0.0)$ & $523(88)$ & 2005 & 2007 & $22.8(3.2)$ \\
\hline $\begin{array}{l}\text { Bird's Hill, MB } \\
\text { (BIR) }\end{array}$ & $\begin{array}{l}50^{\circ} 00^{\prime} \mathrm{N} \\
97^{\circ} 00^{\prime} \mathrm{W}\end{array}$ & Pasture & Heavy Clay & $8.3(0.1)$ & $538(91)$ & 2005 & 2007 & $\mathrm{~N} / \mathrm{A}^{\dagger \dagger}$ \\
\hline $\begin{array}{l}\text { Sault Ste Marie, } \\
\text { ON (SSM) }\end{array}$ & $\begin{array}{l}46^{\circ} 32^{\prime} \mathrm{N} \\
84^{\circ} 24^{\prime} \mathrm{W}\end{array}$ & $\begin{array}{l}\text { Managed } \\
\text { forest }\end{array}$ & $\begin{array}{c}\text { Sandy Clay } \\
\text { Loam }\end{array}$ & $5.4(0.1)$ & $826(56)$ & 2006 & 2008 & $6.1(0.3)$ \\
\hline $\begin{array}{l}\text { Guelph, ON } \\
\text { (GUE) }\end{array}$ & $\begin{array}{l}43^{\circ} 33^{\prime} \mathrm{N} \\
80^{\circ} 13^{\prime} \mathrm{W}\end{array}$ & Turf grass & Clay Loam & $6.9(0.0)$ & $971(143)$ & $2005^{\#}$ & 2008 & $9.5(2.5)$ \\
\hline $\begin{array}{c}\text { Pickering, ON } \\
\text { (PIC) }\end{array}$ & $\begin{array}{l}44^{\circ} 00^{\prime} \mathrm{N} \\
79^{\circ} 01^{\prime} \mathrm{W}\end{array}$ & $\begin{array}{l}\text { Idle/Failed } \\
\text { plantation }\end{array}$ & Clay & $6.8(0.2)$ & $948(131)$ & 2006 & 2008 & $14.0(2.1)$ \\
\hline
\end{tabular}




\subsection{Laboratory Analyses}

Differences in soil chemistry compared soil $\mathrm{C}, \mathrm{NO}_{3}, \mathrm{NH}_{4}, \mathrm{P}, \mathrm{K}, \mathrm{Ca}, \mathrm{Mg}, \mathrm{Na}$, and $\mathrm{pH}$ between the plantation and reference plots. Soils were ground and sieved to $<2 \mathrm{~mm}$. Total soil $\mathrm{C}$ was determined by infrared detection on a LECO C Analyzer (LECO Corporation, St. Joseph, MI, USA) at $1100{ }^{\circ} \mathrm{C}$. Nitrate and $\mathrm{NH}_{4}$ ions were extracted using $2.0 \mathrm{M} \mathrm{KCl}$ and analyzed on a Technicon AutoAnalyzer (Technicon Instruments Corporation, Tarrytown, NY, USA). Soil P was leached using a modified mixture of $\mathrm{H}_{2} \mathrm{SO}_{4}-\mathrm{H}_{2} \mathrm{O}_{2}$ from Kalra and Maynard [27] and measured colorimetrically with a SmartChem instrument (Mandel Scientific Company Inc., Guelph, ON, USA). Exchangeable K, Ca, $\mathrm{Mg}, \mathrm{Na}, \mathrm{Fe}$, and $\mathrm{Al}$ were extracted via a $0.1 \mathrm{M} \mathrm{BaCl}_{2}$ solution [28] and analyzed by atomic emission (K, Na) or absorption (Ca, Mg) spectroscopy (SpectraAA 220, Varian Analytical Instruments). Soil pH was measured in a 2:1 water to soil ratio on a weight basis. Particle size distribution (soil texture) of the upper $20 \mathrm{~cm}$ plantation soils was also analyzed on a Horiba Partica LA-950 laser particle analyzer (Horiba Instruments, Irvine, CA, USA) and corrected for clay content using the pipette method [29]. Soil bulk density was not measured in this study but rather was calculated from soil texture [30] to estimate changes in soil nutrient pools due to afforestation.

The 1-2 kg stem subsamples were chipped and mixed to ensure homogeneity. Two samples per plot of approximately $40 \mathrm{~g}$ were then ground in stages to produce a fine homogeneous powder. This powder was then analyzed for concentrations of $\mathrm{C}, \mathrm{N}, \mathrm{P}, \mathrm{K}, \mathrm{Ca}$, and $\mathrm{Mg}$. Carbon and $\mathrm{N}$ of leaves were determined by infrared detection on a LECO CNS-2000 (LECO Corporation, St. Joseph, MI, USA) at $800{ }^{\circ} \mathrm{C}$. A concentrated mixture of $\mathrm{H}_{2} \mathrm{SO}_{4}-\mathrm{H}_{2} \mathrm{O}_{2}$ was used to digest foliage for subsequent $\mathrm{P}, \mathrm{K}, \mathrm{Ca}$, and $\mathrm{Mg}$ analysis [27]. Concentrations of $\mathrm{PO}_{4}$ were measured colorimetrically using a SmartChem instrument. Potassium, $\mathrm{Ca}$, and $\mathrm{Mg}$ were determined by atomic emission $(\mathrm{K})$ and absorption $(\mathrm{Ca}, \mathrm{Mg})$ spectroscopy. Nutrient removal rates were calculated from the mass of harvested stems [24,25] and their concentrations of $\mathrm{N}, \mathrm{P}, \mathrm{K}, \mathrm{Ca}$, and $\mathrm{Mg}$. Nutrient removal rates in biomass were compared to changes in soil nutrient pools.

\subsection{Statistical Analyses}

Differences in soil properties between plantation and reference soils were detected at individual sites using the Student's $t$-test. Effects of land use change across all sites were tested using paired $t$-tests. $p<0.10$ was chosen as differences are likely difficult to detect after only 3 years given the large amount of natural variability in this landscape scale study. Additionally, it was deemed most important to identify potential changes rather than attain high degrees of certainty that detected changes are indeed occurring. This is because long term studies will need to re-evaluate changes at the end of a plantation's lifespan regardless. Significant effects were further investigated by graphical interpretation of differences. Logarithmic transformation was performed as necessary to ensure normality in the residuals and equal variance. Statistical analyses were conducted in CoStat Ver. 6.1 (CoHort Software, Monterey, CA, USA).

The nature and direction of change was examined graphically for various soil properties. The nine sites included in this study represent a wide range of physiographic conditions which affect the magnitude, direction and nature of soil chemical changes with plantation establishment. The net effect 
on soil chemistry depends upon the initial condition of the soil (e.g., initial concentration of K), the exchange capacity of the soil, and the ability of willow to alter the soil (i.e., by uptake, weathering, sequestration, etc.). By using the reference sites as a proxy for initial concentration, it is possible to represent change from plantation establishment as a function of initial conditions.

The analysis thus makes the assumption that the reference sites are at a steady state and accurately reflect the conditions of the plantation immediately prior to establishment. After making these assumptions, the values can be applied for different soil properties from the reference soils as the initial concentration for both the reference site and the plantation. Therefore, a 1:1 line can be produced when initial concentration of the reference site is on the $x$-axis and concentration after the first rotation is on the $y$-axis. This is because the $x$ and $y$ values for the reference site are the same value according to the assumption of steady state. Linear regression of the reference ( $x$-axis) and plantation ( $y$-axis) yields a line that can be visually and statistically compared to the 1:1 line (i.e., the reference site), with any deviation from the 1:1 line indicating a change resulting from plantation establishment. Differences in slope, tested against a slope of 1.0, and differences in intercept also describe the nature of the change. A slope of $<1.0$ describes a negative feedback, meaning that there is either more depletion or less accumulation at higher initial concentrations. A slope of $>1.0$ indicates a positive feedback where soils with high initial concentrations increase more or are able to better buffer changes than those with lower initial concentrations. The intersection point of the two lines occurs at their steady state concentration. A slope of one indicates that any change is independent of initial conditions. By examining the dataset as a whole, the effects of within site variability on the accuracy of the reference site as an estimate of the true initial conditions is minimized.

\section{Results and Discussion}

Concentrations of nutrients in $S$. purpurea "Hotel" (mean of $6.4,0.87,5.2$ and $0.75 \mathrm{mg} \cdot \mathrm{g}^{-1} \mathrm{~N}, \mathrm{P}, \mathrm{Ca}$ and $\mathrm{Mg}$, respectively) were found to be within the expected range for Salix spp., with the exception of $\mathrm{K}$, which was lower in this study (mean of $2.1 \mathrm{mg} \cdot \mathrm{g}^{-1} v s$. expected range of $2.9-3.4 \mathrm{mg} \cdot \mathrm{g}^{-1}$ ) [4,5,31]. Nutrient exports in harvested biomass were limited primarily by productivity rates, with the most productive LAK, POR, and PIC and to lesser extent GUE exporting the most nutrients (Table 2).

Table 2. Potential nutrient removal as determined from total nutrient content (N, P, K, Ca, and $\mathrm{Mg}$ ) of harvested biomass (stems) by S. purpurea "Hotel" in seven plantations.

\begin{tabular}{cccccc}
\hline & \multicolumn{5}{c}{ Nutrient Content } \\
\cline { 2 - 6 } Site & $\mathbf{N}$ & $\mathbf{P}$ & $\mathbf{K}$ & $\mathbf{C a}$ & $\mathbf{M g}$ \\
\cline { 2 - 6 } & \multicolumn{5}{c}{$\cdot \mathbf{h a}^{-\mathbf{1}}$} \\
\hline SMO & 39.7 & 5.7 & 15.2 & 27.1 & 3.7 \\
LAK & 125.4 & 12.4 & 35.9 & 90.9 & 14.3 \\
UOS & 37.8 & 5.1 & 16.9 & 21.7 & 7.1 \\
POR & 103.3 & 15.4 & 40.6 & 119.4 & 15.3 \\
SSM & 41.4 & 3.9 & 9.3 & 35.1 & 4.4 \\
PIC & 100.0 & 15.2 & 28.9 & 73.4 & 6.0 \\
GUE & 51.4 & 9.4 & 15.4 & 56.6 & 5.9 \\
Mean & 71.3 & 9.6 & 23.2 & 60.6 & 8.1 \\
\hline
\end{tabular}


Soils were also widely variable across the sites. Across the reference sites, for example, total C varied from 21.5 to $70.7 \mathrm{mg} \cdot \mathrm{g}^{-1}$, inorganic $\mathrm{N}$ from 2.62 to $22.0 \mu \mathrm{g} \cdot \mathrm{g}^{-1}$, leachable $\mathrm{P}$ from 0.33 to $1.18 \mathrm{mg} \cdot \mathrm{g}^{-1}$, exchangeable $\mathrm{Ca}$ from 1.66 to $40.1 \mathrm{cmol}_{\mathrm{c}} \cdot \mathrm{kg}^{-1}$ and exchangeable $\mathrm{K}$ from 0.09 to $1.55 \mathrm{cmol}_{\mathrm{c}} \cdot \mathrm{kg}^{-1}$ (see Figures 1 to 6 for site details). Soil texture across the sites also varied greatly from sandy loam to heavy clay [26] in the upper $20 \mathrm{~cm}$. Despite the large differences in soil texture, only SMO had a significant coarse fraction (i.e., $>2 \mathrm{~mm}$ ). This substantial range in both nutrient exports in harvested biomass and soil conditions suggests that there is a large difference in the potential for willow to affect soil chemistry and nutrient availability across the sites and confirms the need for statistical analyses to be inclusive to detect differences amongst high natural variability (i.e., $p \leq 0.10)$.

\subsection{Soil Carbon}

Total $\mathrm{C}$ in the upper $20 \mathrm{~cm}$ of mineral soil was significantly lower in plantations regardless of the initial concentrations (Table 3, Figure 1). At the 20-40 cm depth, there was much more variability in soil $\mathrm{C}$ but overall soil $\mathrm{C}$ remained stable (Table 3, Figure 1).

Figure 1. Initial concentration of total soil $\mathrm{C}$, as estimated from reference sites, versus total soil C concentration in plantations after the first rotation of nine S. purpurea "Hotel" plantations (ELL, SMO, LAK, UOS, POR, BIR, SSM, GUE, and PIC). Error bars represent standard error when greater than symbol size.

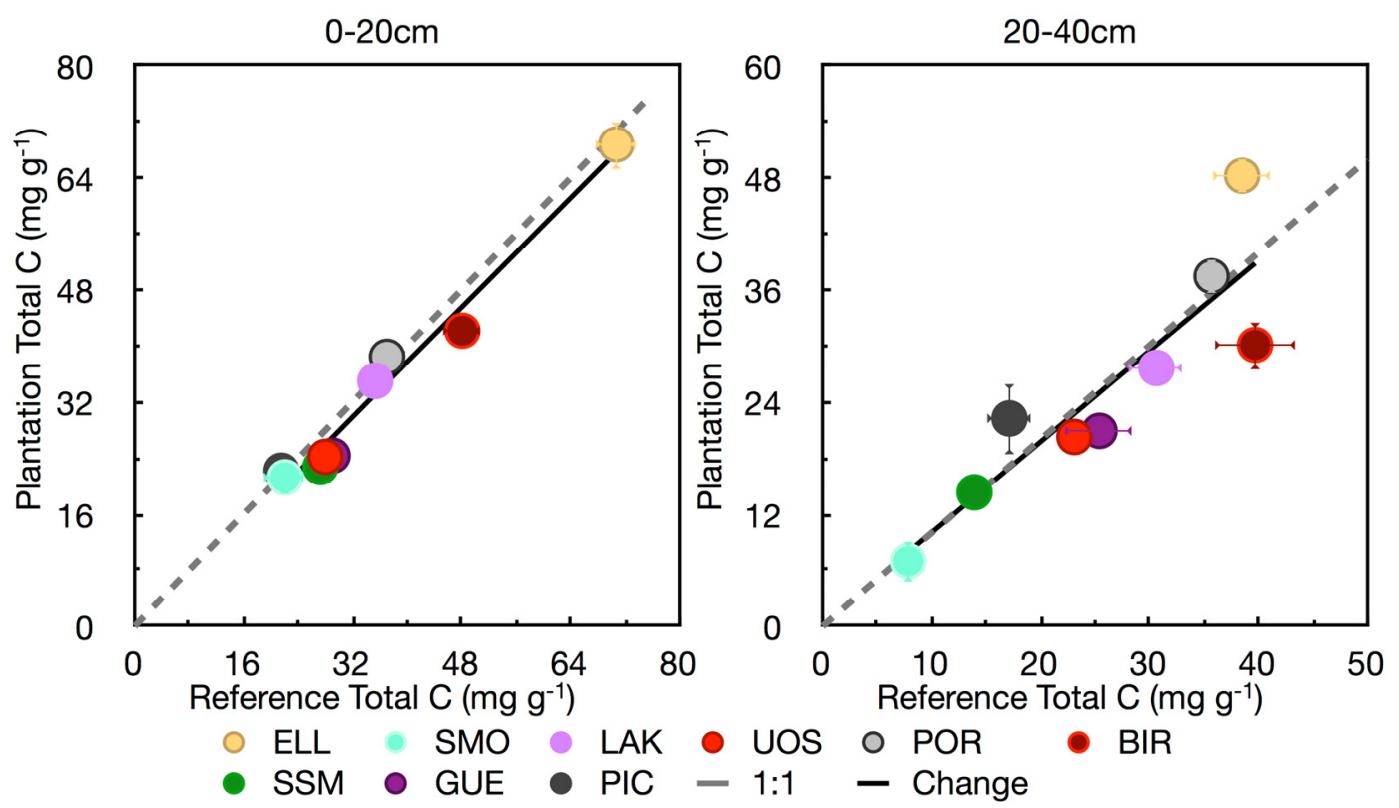


Table 3. Mean pairwise differences between $S$. purpurea "Hotel" plantation and reference soils for nine sites (ELL, SMO, LAK, UOS, POR, BIR, SSM, GUE, and PIC).

\begin{tabular}{lcc}
\hline Variable & $\mathbf{0 - 2 0} \mathbf{~ c m}$ & $\mathbf{2 0 - 4 0 ~ c m}$ \\
\hline Total $\mathrm{C}\left(\mathrm{mg} \cdot \mathrm{g}^{-1}\right)$ & $-2.22^{*}$ & -0.43 \\
Inorganic $\mathrm{N}\left(\mu \mathrm{g} \cdot \mathrm{N} \cdot \mathrm{g}^{-1}\right)$ & $-3.12^{\dagger}$ & $-2.60^{\dagger}$ \\
$\mathrm{NH}_{4}\left(\mu \mathrm{g} \cdot \mathrm{N} \cdot \mathrm{g}^{-1}\right)$ & $-0.95^{\dagger}$ & $-1.38^{\dagger}$ \\
$\mathrm{NO}_{3}\left(\mu \mathrm{g} \cdot \mathrm{N} \cdot \mathrm{g}^{-1}\right)$ & $-2.17^{\dagger}$ & $-1.22^{\dagger}$ \\
Leachable P $\left(\mathrm{mg} \cdot \mathrm{g}^{-1}\right)$ & $-0.03^{\dagger}$ & $-0.02^{\dagger}$ \\
Exchangeable cations & & \\
$\mathrm{K}\left(\mathrm{cmol}_{\mathrm{c}} \cdot \mathrm{kg}^{-1}\right)$ & $-0.11^{\dagger}$ & $-0.10^{\dagger}$ \\
$\mathrm{Ca}\left(\mathrm{cmol}_{\mathrm{c}} \cdot \mathrm{kg}^{-1}\right)$ & $-2.10^{*}$ & $-2.57^{*}$ \\
$\mathrm{Mg}\left(\mathrm{cmol}_{\mathrm{c}} \cdot \mathrm{kg}^{-1}\right)$ & 0.30 & -0.11 \\
$\mathrm{Na}\left(\mathrm{cmol}_{\mathrm{c}} \cdot \mathrm{kg}^{-1}\right)$ & $-0.05^{\dagger}$ & $0.04^{\dagger}$ \\
\hline
\end{tabular}

* Significant at 0.05 probability level of the mean comparison to $0 ;{ }^{\dagger}$ Significant at 0.10 probability level of the mean comparison to 0 .

Paul et al. [11] described an initial soil C loss associated with afforestation on both cropped and pasture land. This is, however, a reversible one-time event associated with the disturbance of soil and vegetative communities and the time it takes for primary productivity (and in turn, litter input) to recover (3-35 years) before a gradual increase in soil $\mathrm{C}$ [11]. The data from this study supports the expected outcome that there is an initial loss of soil $\mathrm{C}$ with plantation establishment. Soil organic $\mathrm{C}$ in the upper $20 \mathrm{~cm}$ of soil showed a consistent loss across sites, regardless of the initial concentrations (Table 3, Figure 1). However, at the 20-40 cm depth, soil C remained stable (Table 3, Figure 1). Trees tend to accumulate $\mathrm{C}$ at the surface from litterfall and have a greater proportion of roots deeper in the soil profile compared to grasses [32]. Consequently, afforestation has been shown to redistribute soil C both deeper in the soil profile and in the forest floor such that soil $\mathrm{C}$ levels in the upper mineral soil may be depleted but total soil $\mathrm{C}$ pools remain unchanged $[32,33]$. As such, it is expected that total soil $\mathrm{C}$ will rise in subsequent years in large part due to the development of a litter layer.

If the accumulation of coarse woody roots was included in the $C$ budget, however, one would probably realize that planting trees has benefits on overall below ground $\mathrm{C}$ sequestration beyond solely soil C [23]. Extensive research has been conducted into the effect of $C$ storage with land use change. For any given soil, the stable concentration of soil $\mathrm{C}$ is generally greatest for pastures and forests, followed by plantations and finally cultivated soils [21]. This relationship can be explained by the allocation of $\mathrm{C}$ in grasses compared to trees. Grasses produce copious fine roots which turn over rapidly, adding $\mathrm{C}$ to the soil. Trees, on the other hand, allocate a greater proportion of their $\mathrm{C}$ to aboveground stems. They also produce larger, woodier and longer lived roots which do not add the same supply of organic inputs to the soil. Therefore, soils in tree dominated systems tend to have less soil $\mathrm{C}$ than do grasses in similar physiographic regions, although total system $\mathrm{C}$ can be much greater and large amounts of $\mathrm{C}$ are stored below ground as woody roots [23].

It is also worth noting that the loss in soil $\mathrm{C}$ was greatest at the plantations that were established on sites previously vegetated by perennial grasses or trees (SMO, LAK, BIR, SSM, GUE, and POR). At these sites, reviews by Guo and Gifford [21] and Laganière et al. [23] suggest that soil C may not fully recover within the 20-30 year life expectancy of a willow plantation. The recovery process will be 
greatly affected by the continued management of plantations as with traditional agriculture on grassland $\mathrm{C}$ stocks. Tillage is known to enhance microbial decomposition, thereby decreasing soil $\mathrm{C}$ through the turning of soil and the breakup of soil aggregates [34]. Therefore, the amount of $\mathrm{C}$ stored in a plantation soil is greatest when soil disturbance is minimized as with no-till farming [35]. This is an important consideration as, depending on management strategies, willow plantations may receive far more frequent disturbance than more typical plantations, owing to their short rotation length. Tilled sites also tend to lack the diversity of macrofauna, including earthworms, that enhance the formation of stable aggregates [36]. Controlling the understory (competing) plants also removes an important $\mathrm{C}$ source [37].

\subsection{Nitrogen}

Nitrate and $\mathrm{NH}_{4}$ ions were significantly depleted at both soil depths (Table 3). At sites where inorganic $\mathrm{N}$ concentrations were initially high in the upper $20 \mathrm{~cm}$ of soil, both $\mathrm{NO}_{3}$ and $\mathrm{NH}_{4}$ ions were depleted but there was a much more pronounced effect on $\mathrm{NO}_{3}$ (slope $=-0.065, \mathrm{NO}_{3}$; slope $=0.646$, $\mathrm{NH}_{4}$; Figure 2). This effect (slopes $<1.0$ ) is enhanced by SMO receiving $\mathrm{N}$ fertilizers such that the true slope may be slightly higher, but the trend remains even with SMO excluded. Negative correlations between inorganic $\mathrm{N}$ at the end of the rotation and plantation yields were also found (total inorganic $\mathrm{N}$, $r=-0.88 ; \mathrm{NO}_{3}, r=-0.87 ; \mathrm{NH}_{4}, r=-0.31$, results not shown).

Figure 2. Initial concentration of $\mathrm{NO}_{3}$ and $\mathrm{NH}_{4}$ as estimated from reference sites, versus $\mathrm{NO}_{3}$ and $\mathrm{NH}_{4}$ in plantations after the first rotation of nine $S$. purpurea "Hotel" plantations (ELL, SMO, LAK, UOS, POR, BIR, SSM, GUE, and PIC). Error bars represent standard error when greater than symbol size.

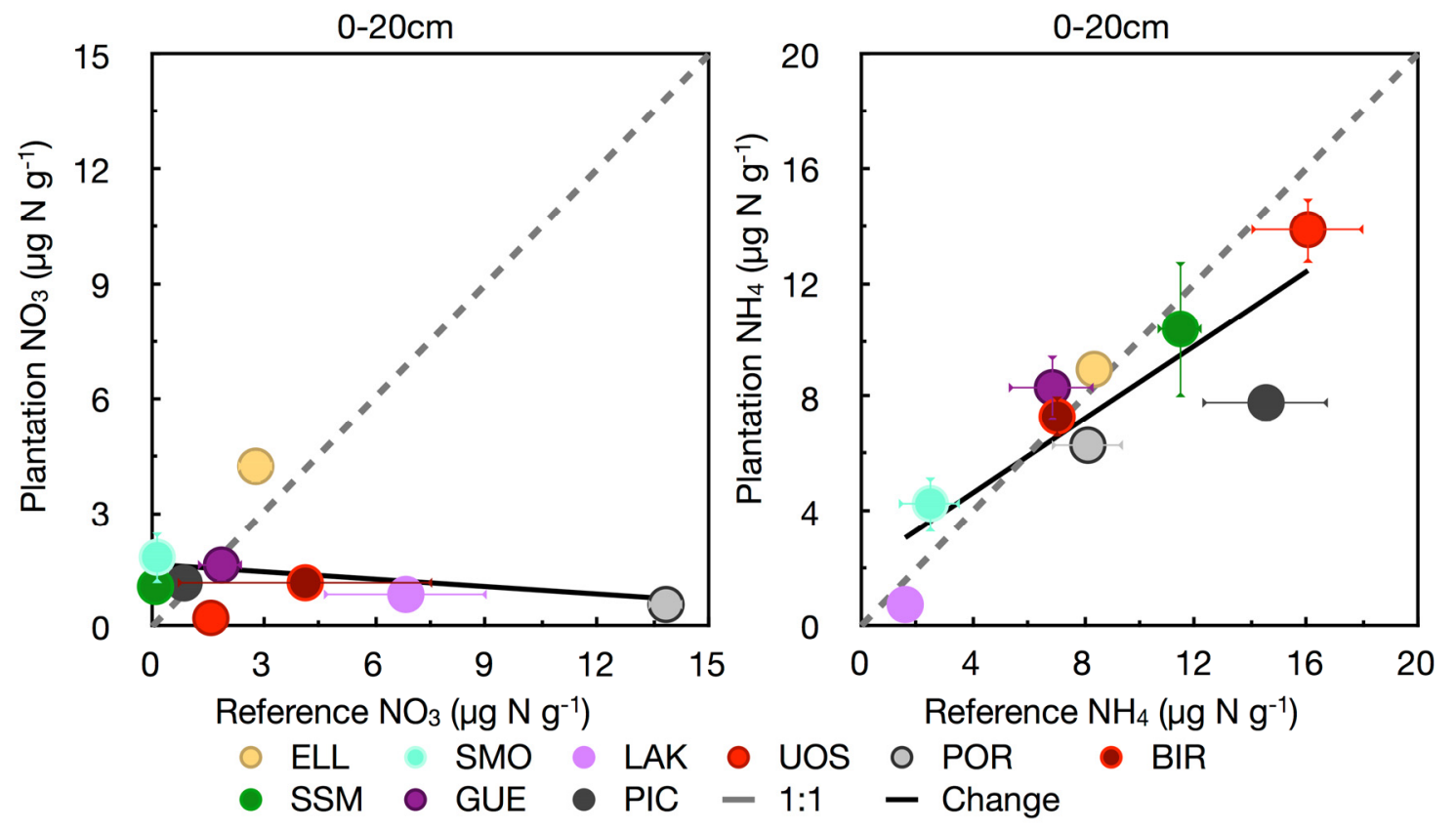

The decline in soil $\mathrm{NO}_{3}$ and $\mathrm{NH}_{4}$ can be explained as an increase in uptake for available $\mathrm{N}$ as willow trees are known to be highly demanding of $\mathrm{N}$, especially when they are planted at very high densities as with SRIC [12]. Greater tree growth (and in turn N uptake) leads to more pronounced 
depletion of soil available $\mathrm{N}$ as evidenced by negative correlation between net changes of soil inorganic $\mathrm{N}$ and plantation yields. This indicates that the rate of uptake of $\mathrm{N}$ by willow exceeds the maximum rate of mineralization.

The results could be viewed as being positive in terms of the environmental impact - the depletion of the soil in $\mathrm{N}$ results in less $\mathrm{NO}_{3}$ leaching and less potential for the release of nitrous oxide from denitrification [38]. However, it also indicates that the willow trees are highly $\mathrm{N}$ demanding and will likely require amendments with synthetic $\mathrm{N}$ fertilizers to enhance or maintain productivity unless alternative less energy-intensive systems are developed (e.g., suitable N-fixing companion species in SRIC of willow [39]). The use of $\mathrm{N}$ fertilizers within bioenergy plantations will decrease the energy ratio and greenhouse gas balance [40], although it may be possible to use small amounts of $\mathrm{N}$ fertilizers and achieve increases in net energy production [41].

\subsection{Phosphorus}

Losses in leachable $\mathrm{P}$ were small but significant at both soil depths (Table 3). Leachable $\mathrm{P}$ was found to be depleted with increasing initial concentrations (Figure 3). At lower initial concentrations, there was a tendency towards more stable or increasing leachable P pools. It must be noted that part of this difference is due to an inadequate reference match at the SMO site. At SMO, soil leachable P in the willow plantation was compared to the surrounding forest. The plantation had received P fertilizers in its recent history, thereby falsely indicating a willow induced rise in soil leachable $\mathrm{P}$ with establishment. Thus, when SMO was excluded from the analysis, there was an overall soil loss of $0.07 \mathrm{mg} \cdot \mathrm{P} \cdot \mathrm{g}^{-1}(p<0.01)$, i.e., four sites being depleted in soil leachable P (ELL, UOS, BIR, and GUE; $p<0.05$ ) and four sites being unchanged (LAK, POR, SSM, and PIC; $p<0.05$ ). This is unlike many studies that show an increase in soil available $\mathrm{P}$ with afforestation (see review by Chen et al. [42]).

Figure 3. Initial concentration of acid leachable $\mathrm{P}$, as estimated from reference sites, versus acid leachable $\mathrm{P}$ concentration in plantations after the first rotation of nine $S$. purpurea "Hotel” plantations (ELL, SMO, LAK, UOS, POR, BIR, SSM, GUE, and PIC). Error bars represent standard error when greater than symbol size.

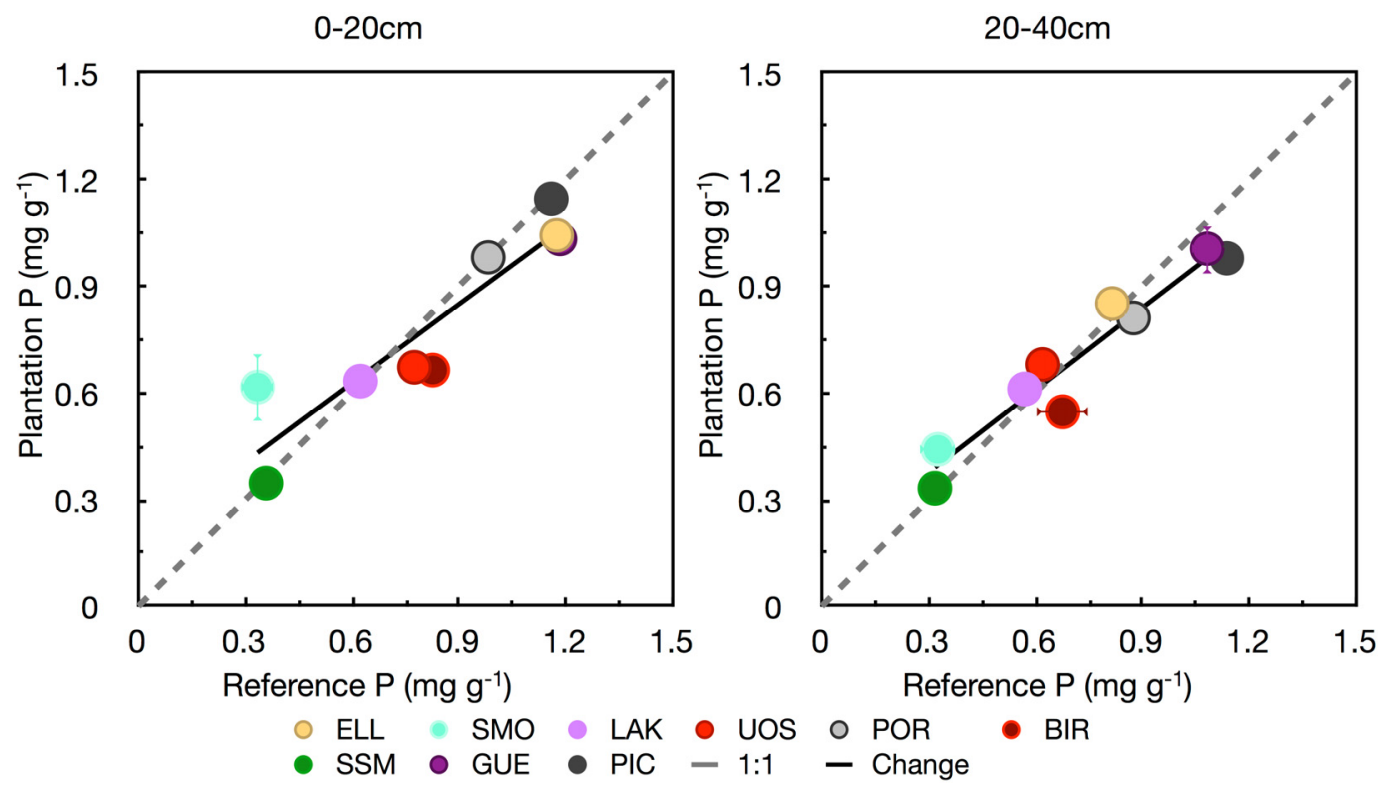


Decreases in the organic fraction of soil $\mathrm{P}$ have been reported with site disturbance [18] and afforestation [43]. The decline in mineral soil $\mathrm{P}$ is described as largely a result of the migration of soil $\mathrm{P}$ into the tree leaves through uptake by the roots and then translocated back to the soil as litterfall to form the forest floor - the inclusion of the newly created forest floor into the $\mathrm{P}$ budget can easily account for the losses in the mineral soil [43]. However, the magnitude of the decrease at UOS and GUE was far greater than can be attributed to the estimated uptake, even if a generous assumption that only $20 \%$ of total $\mathrm{P}$ uptake was contained in harvestable stems (e.g., 10.4 and $17.9 \mathrm{mg} \cdot \mathrm{P}^{\mathrm{kg}} \mathrm{kg}^{-1}$ attributable to uptake to harvestable stems vs. 103 and $150 \mathrm{mg} \cdot \mathrm{P} \cdot \mathrm{kg}^{-1}$ soil decrease, respectively). The establishment phase of the plantation could well be associated with increased losses of $\mathrm{P}$, as degradation of organic matter from the previous land use continues but trees are still too small to recycle the released P [18]. Indeed, UOS and GUE had lower rates of productivity while ELL and BIR had been coppiced recently, thereby preventing efficient $\mathrm{P}$ cycling to reestablish. On the other hand, the three sites with the fastest growth rates (LAK, POR, and PIC) had no change in total P. Productivity at SSM was low but so too was the initial leachable P concentration of the soil such that there was no change despite low rates of uptake.

Therefore, the results show that $\mathrm{P}$ may be efficiently cycled within plantations where $\mathrm{P}$ availability is matched by sufficiently high productivity. However, substantial losses during establishment may occur when $\mathrm{P}$ availability is high but productivity is low such as conversion from $\mathrm{P}$ fertilized crops when willow growth is limited by factors other than $\mathrm{P}$ [44].

\subsection{Base Cations}

Soil exchangeable $\mathrm{K}$ was found to be depleted at both $0-20$ and $20-40 \mathrm{~cm}$ depths as a result of plantation establishment (Table 3). Losses in soil exchangeable $\mathrm{K}$ occurred where initial concentrations of $\mathrm{K}$ were the highest (Figure 4). As well, losses were correlated with willow yields ( $r=0.83 ; p=0.02$, results not shown). Thus, where soils are high in $\mathrm{K}$ and support high yields, $\mathrm{K}$ was depleted in the soils (Table 3, Figure 4). Certainly, harvestable stems do not contain all of the K sequestered by the willow but the detected changes are greater than can be explained by uptake alone (e.g., $89.3 \mathrm{mg} \cdot \mathrm{K} \cdot \mathrm{g}^{-1}$ soil uptake vs. $173 \mathrm{mg} \cdot \mathrm{K} \cdot \mathrm{g}^{-1}$ soil loss at POR assuming $20 \%$ of uptake contained in harvestable stems). Site disturbance and the subsequent release of immobilized $\mathrm{K}$ has previously been shown to dramatically increase export of dissolved K [45]. Additionally, losses in soil C will have resulted in fewer exchange sites to which $\mathrm{K}$ can absorb [mean cation exchange capacity (CEC) decreased $1.97 \mathrm{cmol}_{\mathrm{c}} \cdot \mathrm{kg}^{-1}$ in our study]. Thus, $\mathrm{K}$, being readily soluble, is affected by site disturbance and changes in water use associated with vegetation removal and reestablishment of tree species [45]. Decreased water use, in the establishment year, allows for increased drainage, thereby multiplying losses of soil solution K and eventually soil exchangeable K. Subsequent increases in transpiration from the previous land use by the second or third year may draw down the water table and translocate mobile $\mathrm{K}$ to the subsoil.

It is important to note that $\mathrm{K}$ has been shown to remain in this enhanced state of mobility several years after disturbance and revegetation has occurred [45]. This allows for the continuation of leaching even while uptake increases due to tree growth. As such, correlation analysis suggests that soil exchangeable $\mathrm{K}$ depletion was exacerbated by increasing productivity and uptake. At high initial 
concentrations of exchangeable $\mathrm{K}$ and at higher rates of productivity, like inorganic $\mathrm{N}$, soil exchangeable $\mathrm{K}$ depletion is greater. This would indicate that willow trees are taking up copious amounts of $\mathrm{K}$ when available such that the threshold concentration supporting high growth rates may be unsustainable. This is of concern for the maintenance of long term productivity, as $\mathrm{K}$ is also found to be correlated with greater leaf nutrition and stem growth [25]. At lower initial concentrations, the trees would seem to be effectively cycling $\mathrm{K}$ but this may be at suboptimal productivity.

Figure 4. Initial concentration of exchangeable $\mathrm{K}$, as estimated from reference sites, versus exchangeable $\mathrm{K}$ concentration in plantations after the first rotation of nine $S$. purpurea "Hotel" plantations (ELL, SMO, LAK, UOS, POR, BIR, SSM, GUE, and PIC). Error bars represent standard error when greater than symbol size.
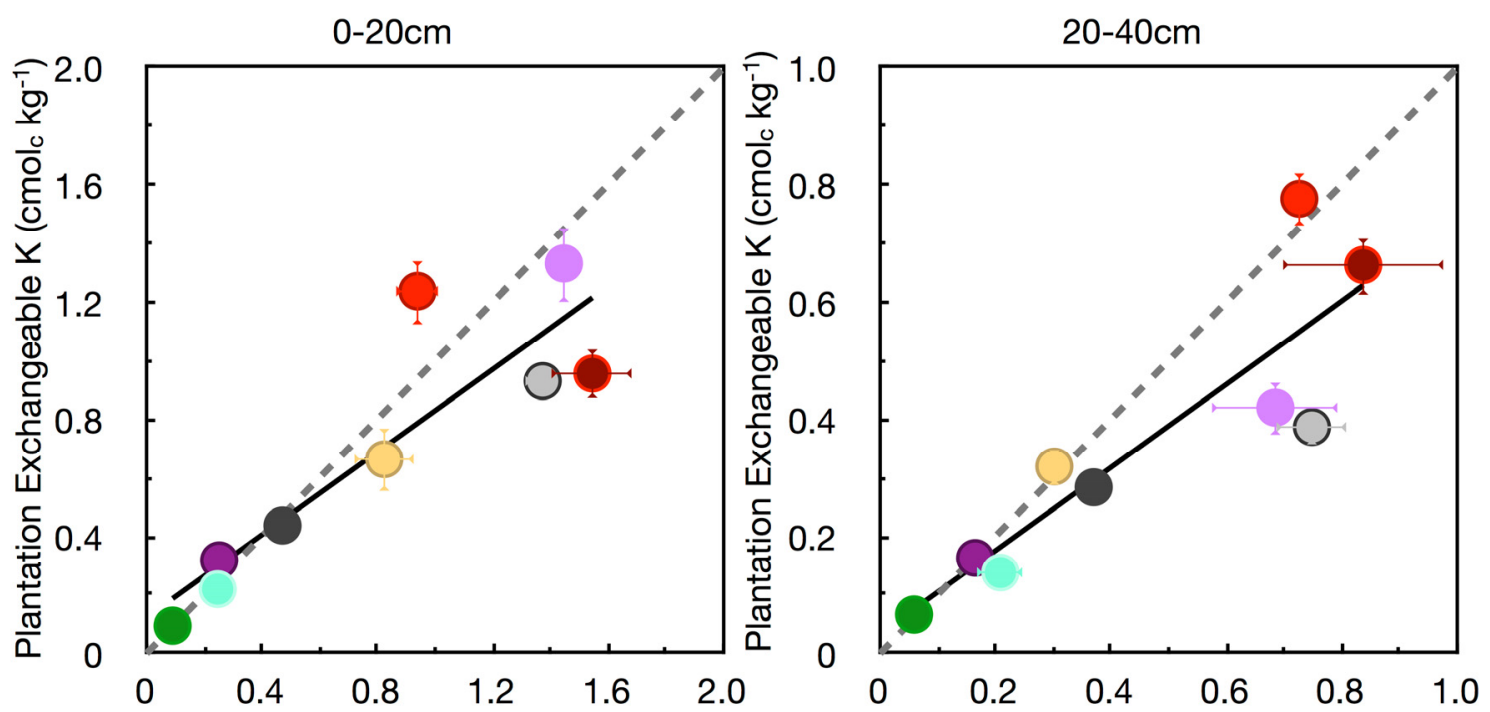

Reference Exchangeable $\mathrm{K}\left(\mathrm{cmol}_{\mathrm{c}} \mathrm{kg}^{-1}\right)$

Reference Exchangeable $\mathrm{K}\left(\mathrm{cmol}_{\mathrm{c}} \mathrm{kg}^{-1}\right)$

ELL

SMO

LAK

UOS O POR

- BIR

SSM

- GUE

- $\mathrm{PIC}-1: 1 \quad$ - Change

Paired $t$-tests indicated that there was a significant and substantial loss of soil exchangeable Ca at both depths (Table 3). Closer examination with site by site $t$-tests revealed, however, that this result for the 0-20 cm depth was forced by a single site, i.e., LAK, and that no other site shared in this loss (Figure 5). LAK was among 4 other sites (UOS, BIR, POR, and PIC) that showed an actual loss in exchangeable $\mathrm{Ca}$ with plantation establishment at the 20-40 cm depth (Figure 5). Soil exchangeable $\mathrm{Ca}$ was found to be highly variable in many of the sites studied, particularly when concentrations of exchangeable $\mathrm{Ca}$ were high (Figure 5).

The high demand by willow for $\mathrm{Ca}$ is reflected in the chemical composition of their biomass and seemingly in a decrease in exchangeable soil $\mathrm{Ca}$ with establishment according to initial correlation analysis. However, with the exception of LAK, there was no change in exchangeable soil $\mathrm{Ca}$ in the upper $20 \mathrm{~cm}$ of soil. Furthermore, there was no relationship between initial exchangeable soil Ca or plantation yields and change in exchangeable $\mathrm{Ca}$ at the $20-40 \mathrm{~cm}$ depth. For example, the low productivity and removal with biomass of $\mathrm{Ca}$ at UOS was accompanied by a depletion of soil exchangeable $\mathrm{Ca}$, whereas the high productivity and removal with biomass of $\mathrm{Ca}$ at ELL was not accompanied by a loss of soil Ca (Figure 5). The contrasting responses at UOS and ELL may be 
explained by lower total $\mathrm{Ca}$ at UOS such that losses in exchangeable $\mathrm{Ca}$ are not replaced by weathering as could be the case for ELL with higher total Ca. However, LAK is highly calcareous so this argument opposes the difference seen at this site. It is therefore probably safer to conclude that another factor, along with the presence of fast growing willow and high $\mathrm{Ca}$ demand, caused the differences at LAK at the 0-20 cm depth and at LAK, UOS, BIR, POR, and PIC at the 20-40 cm depth. Site disturbance could be one factor but $\mathrm{Ca}$ is less prone to leaching than $\mathrm{N}$ and $\mathrm{K}$ following disturbance [45]. The lack of change at many of the sites included in this study could also be explained by the large quantities of total $\mathrm{Ca}$, especially in the upper $20 \mathrm{~cm}$ of soil where exchangeable C levels are generally 10 to $20 \%$ higher than in the $20-40 \mathrm{~cm}$ depth.

Figure 5. Initial concentration of exchangeable $\mathrm{Ca}$, as estimated from reference sites, versus exchangeable $\mathrm{Ca}$ concentration in plantations after the first rotation of nine S. purpurea "Hotel" plantations (ELL, SMO, LAK, UOS, POR, BIR, SSM, GUE, and PIC). Error bars represent standard error when greater than symbol size.

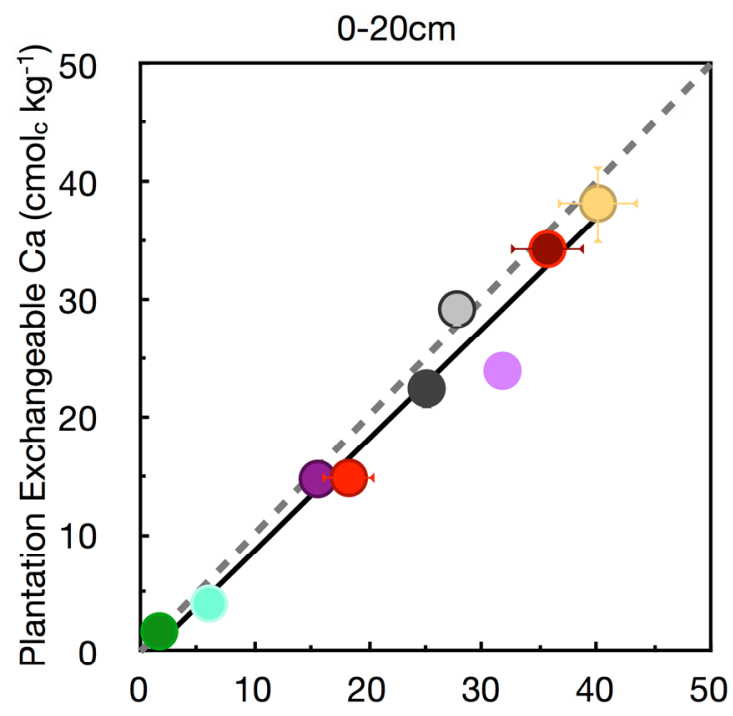

Reference Exchangeable $\mathrm{Ca}\left(\mathrm{cmol}_{\mathrm{c}} \mathrm{kg}^{-1}\right)$

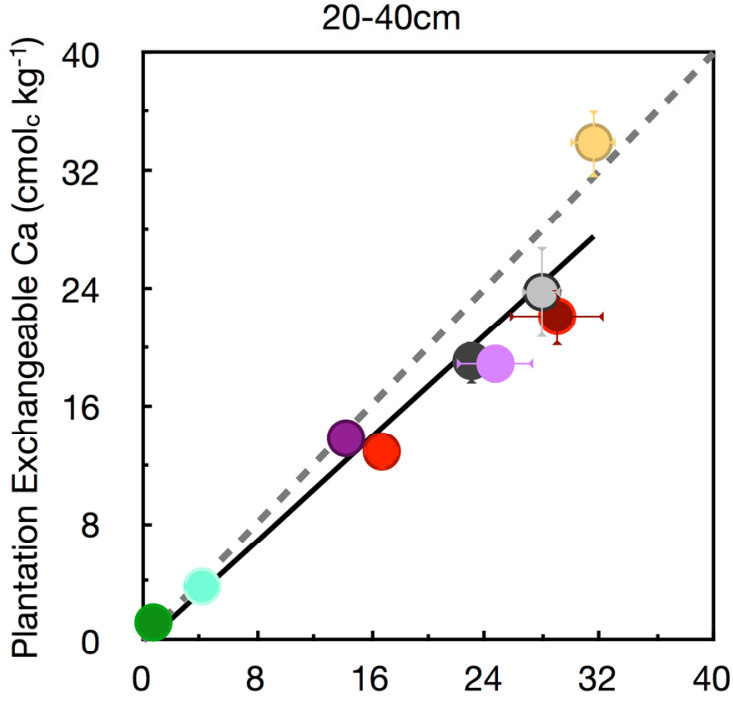

Reference Exchangeable $\mathrm{Ca}\left(\mathrm{cmol}_{\mathrm{c}} \mathrm{kg}^{-1}\right)$

ELL SMO LAK

- UOS O POR

SSM

GUE

- PIC - 1:1 - Change

There was no relationship between soil exchangeable $\mathrm{Mg}$ and plantation establishment (Table 3). Paired $t$-tests indicated a depletion of exchangeable $\mathrm{Na}$ in the upper $20 \mathrm{~cm}$ of soil, which was matched by an increase at the 20-40 cm depth (Table 3, Figure 6). Due to interest in growing willow in marginal land unsuited to traditional agriculture (including sites affected by moderate salinity), the noted decrease in $\mathrm{Na}$ may prove to be beneficial. While only the UOS site had $\mathrm{Ca}: \mathrm{Na}$ ratios $<10$, there was a decrease in $\mathrm{Na}$ in the upper $20 \mathrm{~cm}$ of soil across all sites where detectable quantities of $\mathrm{Na}$ were present (Figure 6). The increased water demand from the willow could be causing a decrease in the water table, resulting in the downward movement of soluble salts [46]. The decreases in $\mathrm{Na}$ at UOS and BIR at 0-20 cm were accompanied by increases at $20-40 \mathrm{~cm}$ (Figure 6), indicating that translocation of $\mathrm{Na}$ has indeed occurred to lower depths. Additionally, $\mathrm{Na}$ concentrations in stems were elevated at UOS $\left(0.058 \mathrm{mg} \cdot \mathrm{g}^{-1}\right.$ vs. mean of $0.022 \mathrm{mg} \cdot \mathrm{g}^{-1}$ for SMO, LAK, POR, SSM, PIC, and GUE) where $\mathrm{Na}$ concentrations were much higher than the other sites $\left(1.06 \mathrm{cmol}_{\mathrm{c}} \cdot \mathrm{kg}^{-1} v s\right.$. mean of 
$0.01 \mathrm{cmol}_{\mathrm{c}} \cdot \mathrm{kg}^{-1}$ for SMO, LAK, POR, SSM, PIC, and GUE). Thus, increased uptake at higher concentrations is also a factor leading to decreased exchangeable soil $\mathrm{Na}$. The ability of willow to decrease $\mathrm{Na}$ concentrations may make them useful for making use of sodic soils not suited to agriculture or for phytoremediation [47].

Figure 6. Initial concentration of exchangeable $\mathrm{Na}$, as estimated from reference sites, versus exchangeable $\mathrm{Na}$ concentration in plantations after the first rotation of nine S. purpurea "Hotel" plantations (ELL, SMO, LAK, UOS, POR, BIR, SSM, GUE, and PIC). Inset shows expanded view of low values. Error bars represent standard error when greater than symbol size.

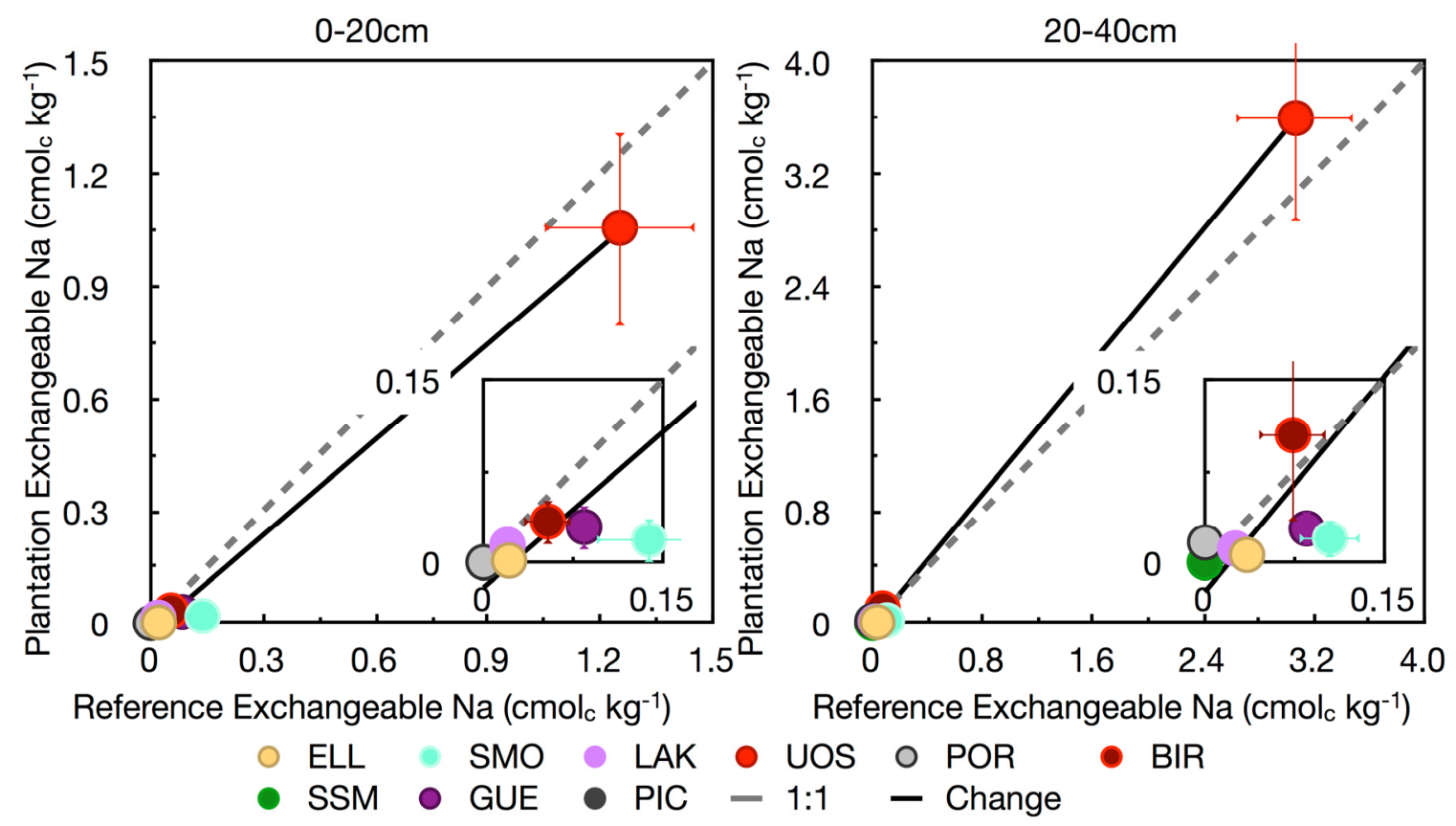

\section{Conclusions}

There was a loss of soil $\mathrm{C}$ after the first three-year willow rotation. Depending on management strategies and the previous land use, this could be a temporary deficit although recovery times are exacerbated in northern latitudes by low productivity [23]. In terms of soil C storage, the endpoint of short rotation intensive culture plantations can be expected to be similar to other plantations, given that soil disturbance is minimized. Reliance on chemical herbicides instead of between row tillage and harvesting in winter on frozen soils will contribute to reducing soil disturbance and maximizing the potential for soil $\mathrm{C}$ recovery. There is, however, little evidence as of yet that willow plantations have any potential to maintain or increase soil $\mathrm{C}$ when established on grasslands (native or pasture) or forests within the mineral soil. Plantations typically have depleted soil $\mathrm{C}$ when compared to these land uses [21]. However, the accumulation of $\mathrm{C}$ in the litter layer was not quantified in this study and may compensate for depleted mineral soil $\mathrm{C}$ [31,32]. SRIC may have an advantage over other plantations as frequent harvesting will leave behind some residue or slash with typical biomass recovery rates ranging between $60 \%-90 \%$, depending on technology used $[48,49]$.

Trees are generally efficient at recycling nutrients under natural conditions but in SRIC, this is disrupted by site disturbance, minimized understory development and removal of large quantities of 
biomass (instead of allowing the nutrients to be returned to the soil through decay of debris and death of trees). Site disturbance has been the dominant influence on soil nutrient status and $\mathrm{C}$ storage during the first three-year rotation. At this stage, the willow plantation has not yet reached its maximum growth potential. It is expected that productivity will rise to approximately $130 \%$ of the initial rotation in subsequent rotations and the roots system will continue to grow and mature [3]. This will greatly increase rates of nutrient use and uptake. Additionally, the majority of the willow in this study was not coppiced after the first year, as is typical. In a coppiced plantation, increased biomass removal, disturbance and productivity may compound the effects of these factors.

After the first rotation, cycling of the various macronutrients is in different stages of recovery and efficiency. Increased demand for $\mathrm{N}$ has resulted in low levels of $\mathrm{NO}_{3}$, thereby decreasing potential for leaching and denitrification. Likewise, sites with greater growth had stabilized $\mathrm{P}$ concentrations; though P may be sensitive to routine disturbances such as coppicing. However, an increasing litter layer may provide a sustained supply of $\mathrm{N}$ and $\mathrm{P}$ in future rotations [43]. Potassium has been shown to have a slow recovery from disturbance and, as such, biologically mediated processes have not been able to keep exchangeable $\mathrm{K}$ levels stable in optimal ranges early in establishment [45]. In terms of plantation establishment, depletion of soil $\mathrm{K}$ and $\mathrm{P}$ was more heavily influenced by disturbance than direct effects of willow uptake as was N. The same biological cycling of nutrients which has kept soil $\mathrm{P}$ relatively stable is much more difficult to achieve with $\mathrm{K}$, likely due to its greater mobility during disturbance.

\section{Acknowledgments}

This study was funded through a Natural Sciences and Engineering Research Council of Canada (NSERC) Strategic Projects Grant, the Saskatchewan Ministry of Agriculture Strategic Rsearch Program, and personal NSERC and College of Graduate Studies and Research (University of Saskatchewan, Saskatoon, Canada) scholarships to J. Ens. We thank the Canadian Forest Service, including D. Sidders, for giving us access to the willow plantations and providing us with historical data for each sites. We are grateful to M. Emigh, A.N. Robertson, L. Pauls, M. Cooke, L. Pennock, R. de Freitas and B. Goetz for their assistance in the field and in the laboratory, M. Emigh, A. N. Robertson, L. Pauls, M. Cooke, L. Pennock, R. de Freitas and B. Goetz.

\section{Conflict of Interest}

The authors declare no conflict of interest.

\section{References}

1. Kopp, R.F.; Smart, L.B.; Maynard, C.A.; Isebrands, J.G.; Tuskan, G.A.; Abrahamson, L.P. The development of improved willow clones for eastern North America. For. Chron. 2001, 77, 287-292.

2. Richards, J.H.; Fung, K.-I. Atlas of Saskatchewan; University of Saskatchewan: Saskatoon, SK, Canada, 1969. 
3. Volk, T.A.; Verwijst, T.; Tharakan, P.J.; Abrahamson, L.P.; White, E.H. Growing fuel: A sustainability assessment of willow biomass crops. Front. Ecol. Environ. 2004, 2, 411-418.

4. Labrecque, M.; Teodorescu, T.I.; Daigle, S. Early performance and nutrition of two willow species in short-rotation intensive culture fertilized with wastewater sludge and impact on the soil characteristics. Can. J. For. Res. 1998, 28, 1621-1635.

5. Adegbidi, H.G.; Volk, T.A.; White, E.H.; Abrahamson, L.P.; Briggs, R.D.; Bickelhaupt, D.H. Biomass and nutrient removal by willow clones in experimental bioenergy plantations in New York State. Biomass Bioenerg. 2001, 20, 399-411.

6. Bauhus, J.; Messier, C. Soil exploitation strategies of fine roots in different tree species of the southern boreal forest of eastern Canada. Can. J. For. Res. 1999, 29, 260-273.

7. Fox, T.R. Sustained productivity in intensively managed forest plantations. For. Ecol. Manage. 2000, 138, 187-202.

8. Attiwill, P.M.; Adams, M.A. Tansley Review No. 50 Nutrient cycling in forests. New Phytol. 1993, 124, 561-582.

9. Binkley, D.; Giardina, C. Why do tree species affect soils? The warp and woof of tree-soil Interactions. Biogeochemistry 1998, 42, 89-106.

10. Augusto, L.; Ranger, J.; Binkley, D.; Rothe, A. Impact of several common tree species of European temperate forests on soil fertility. Ann. For. Sci. 2002, 59, 233-253.

11. Paul, K.I.; Polglase, P.J.; Nyakuengama, J.G.; Khanna, P.K. Change in soil carbon following afforestation. For. Ecol. Manage. 2002, 168, 241-257.

12. Simon, M.; Zsuffa, L.; Burgess, D. Variation in N, P, and K status and N efficiency in some North American willows. Can. J. For. Res. 1990, 20, 1888-1893.

13. Kopinga, J.; van den Burg, J. Using soil and foliar analysis to diagnose the nutritional status of urban trees. J. Arboric. 1995, 21, 17-24.

14. Cornelissen, J.H.C.; Werger, M.J.A.; Castro-Díez, P.; van Rheenen, J.W.A.; Rowland, A.P. Foliar nutrients in relation to growth, allocation and leaf traits in seedlings of a wide range of woody plant species and types. Oecologia 1997, 111, 460-469.

15. Mitchell, C.P.; Stevens, E.A.; Watters, M.P. Short-rotation forestry-Operations, productivity and costs based on experience gained in the UK. For. Ecol. Manage. 1999, 121, 123-136.

16. Bélanger, N.; Paré, D.; Bouchard, M.; Daoust, G. Is the use of trees with superior growth a threat to soil nutrient availability? A case study with Norway spruce. Can. J. For. Res. 2004, 34, $560-572$.

17. Ericsson, T. Growth and nutrition of three Salix clones in low conductivity solutions. Physiol. Plant 1981, 52, 239-244.

18. Bormann, F.H.; Likens, G.E.; Siccama, T.G.; Pierce, R.S.; Eaton, J.S. The export of nutrients and recovery of stable conditions following deforestation at Hubbard Brook. Ecol. Monogr. 1974, 44, 255-277.

19. Quideau, S.; Chadwick, O.; Graham, R.; Wood, H. Base cation biogeochemistry and weathering under oak and pine: A controlled long-term experiment. Biogeochemistry 1996, 35, 377-398.

20. Hobbie, S.E. Effects of plant species on nutrient cycling. Trends Ecol. Evol. 1992, 7, 336-339.

21. Guo, L.B.; Gifford, R.M. Soil carbon stocks and land use change: A meta analysis. Glob. Change Biol. 2002, 8, 345-360. 
22. Olszewska, M.; Smal, H. The effect of afforestation with Scots pine (Pinus silvestris L.) of sandy post-arable soils on their selected properties. I. Physical and sorptive properties. Plant Soil 2008, $305,157-169$.

23. Laganière, J.; Angers, D.A.; Paré, D. Carbon accumulation in agricultural soils after afforestation: A meta-analysis. Glob. Change Biol. 2010, 16, 439-453.

24. Ens, J.A.; Farrell, R.E.; Bélanger, N. Rapid biomass estimation using optical stem density of willow (Salix spp.) grown in short rotation. Biomass Bioenerg. 2009, 33, 174-179.

25. Ens, J. Short Rotation Culture of Willow Clones Across Canada: Growth Requirements and Implications for Soil Nutrients and Greenhouse Gas Balances. Ph.D. Thesis, Department of Soil Science, University of Saskatchewan, Saskatoon, SK, Canada, 2012; p. 158.

26. Soil Calssification Working Group. The Canadian System of Soil Classification; NRC Press: Ottawa, ON, Canada, 1998.

27. Kalra, Y.P.; Maynard, D.G. Methods Manual for Forest Soil and Plant Analysis; Canadian Forest Service, Northern Forestry Centre: Edmonton, AB, Canada, 1999.

28. Hendershot, W.H.; Lalande, H.; Duquette, M. Ion Exchange and Exchangeable Cations. In Soil Sampling and Methods of Analysis, 2nd ed.; Carter, M.R., Gregorich, E.G., Eds.; CRC Press: Boca Raton, FL, USA, 2008; pp. 197-206.

29. Kroetsch, D.; Wang, C. Particle Size Distribution. In Soil Sampling and Methods of Analysis, 2nd ed.; Carter, M.R., Gregorich, E.G., Eds.; CRC Press: Boca Raton, FL, USA, 2008; pp. 713-726.

30. Rawls, W.J. Estimating soil bulk density from particle size analysis and organic matter content. Soil Sci. 1983, 135, 123-125.

31. Jug, A.; Hofmann-Schielle, C.; Makeschin, F.; Rehfuess, K.E. Short-rotation plantations of balsam poplars, aspen and willows on former arable land in the Federal Republic of Germany. II. Nutritional status and bioelement export by harvested shoot axes. For. Ecol. Manage. 1999, 121, $67-83$.

32. Jobbágy, E.G.; Jackson, R.B. The vertical distribution of carbon and its relation to climate and vegetation. Ecol. Applic. 2000, 10, 423-436.

33. Pinno, B.D.; Bélanger, N. Ecosystem carbon gains from afforestation in the Boreal Transition ecozone of Saskatchewan (Canada) are coupled with the devolution of Black Chernozems. Agric. Ecosyst. Environ. 2008, 123, 56-62.

34. Six, J.; Callewaert, P.; Lenders, S.; de Gryze, S.; Morris, S.J.; Gregorich, E.G.; Paul, E.A.; Paustian, K. Measuring and understanding carbon storage in afforested soils by physical fractionation. Soil Sci. Soc. Am. J. 2002, 66, 1981-1987.

35. Turner, J.; Lambert, M. Change in organic carbon in forest plantation soils in eastern Australia. For. Ecol. Manag. 2000, 133, 231-247.

36. Zou, X.; Bashkin, M. Soil carbon accretion and earthworm recovery following revegetation in abandoned sugarcane fields. Soil Biol. Biochem. 1998, 30, 825-830.

37. Woods, P.V.; Nambiar, E.K.S.; Smethurst, P.J. Effect of annual weeds on water and nitrogen availability to Pinus radiata trees in a young plantation. For. Ecol. Manag. 1992, 48, 145-163. 
38. Aronsson, P.G.; Bergström, L.F. Nitrate leaching from lysimeter-grown short-rotation willow coppice in relation to $\mathrm{N}$-application, irrigation and soil type. Biomass Bioenerg. 2001, 21, $155-164$.

39. Moukoumi, J.; Farrell, R.; van Rees, K.; Hynes, R.; Bélanger, N. Intercropping Caragana arborescens with Salix miyabeana to satisfy nitrogen demand and maximize growth. Bioenerg. Res. 2012, 5, 719-732.

40. Crutzen, P.J.; Mosier, A.R.; Smith, K.A.; Winiwarter, W. $\mathrm{N}_{2} \mathrm{O}$ release from agro-biofuel production negates global warming reduction by replacing fossil fuels. Atmos. Chem. Phys. 2008, 8, 389-395.

41. Scott, A.D.; Dean, T.J. Energy trade-offs between intensive biomass utilization, site productivity loss, and ameliorative treatments in loblolly pine plantation. Biomass Bioenerg. 2006, 30, 1001-1010.

42. Chen, C.R.; Condron, L.M.; Xu, Z.H. Impacts of grassland afforestation with coniferous trees on soil phosphorus dynamics and associated microbial processes: A review. For. Ecol. Manag. 2008, 255, 396-409.

43. Chen, C.; Condron, L.; Davis, M.; Sherlock, R. Effects of afforestation on phosphorus dynamics and biological properties in a New Zealand grassland soil. Plant Soil 2000, 220, 151-163.

44. Ellert, B.H.; Gregorich, E.G. Storage of carbon, nitrogen and phosphorus in cultivated and adjacent forested soils of Ontario. Soil Sci. 1996, 161, 587-603.

45. Likens, G.E.; Driscoll, C.T.; Buso, D.C.; Siccama, T.G.; Johnson, C.E.; Lovett, G.M.; Ryan, D.F.; Fahey, T.; Reiners, W.A. The biogeochemistry of potassium at Hubbard Brook. Biogeochemistry 1994, 25, 61-125.

46. Schofield, N.J. Tree planting for dryland salinity control in Australia. Agrofor. Syst. 1992, 20, $1-23$.

47. Hangs, R.D.; Schoenau, J.J.; van Rees, K.C.J.; Steppuhn, H. Examining the salt tolerance of willow (Salix spp.) bioenergy species for use on salt-affected agricultural lands. Can. J. Plant Sci. 2011, 91, 509-517.

48. Schroeder, W.; Kort, J.; Savoie, P.; Preto, F. Biomass harvest from natural willow rings around prairie wetlands. Bioenerg. Res. 2009, 2, 99-105.

49. Gigler, J.K.; Meerdink, G.; Hendrix, E.M.T. Willow supply strategies to energy plants. Biomass Bioenerg. 1999, 17, 185-198.

(C) 2013 by the authors; licensee MDPI, Basel, Switzerland. This article is an open access article distributed under the terms and conditions of the Creative Commons Attribution license (http://creativecommons.org/licenses/by/3.0/). 